\title{
Epidemiological and Histological Profile of Cervical Cancer in Cameroon: About 2078 Cases
}

\author{
Engbang Ndamba Jean Paul ${ }^{1,2,3}{ }^{*}$, Tchente Nguefack Charlotte ${ }^{1,4}$, Owona Manga Léon Jules ${ }^{1}$, \\ Simo Godefroy5, Essam Sime Jean Daniel6, Elono Fouda Andrée Michelle2, \\ Essame Oyono Jean Louis 7,8 , Hasigov Alan ${ }^{3}$ \\ ${ }^{1}$ Faculty of Medicine and Pharmaceutical Sciences, The University of Douala, Douala, Cameroon \\ ${ }^{2}$ Laquintinie Hospital of Douala, Douala, Cameroon \\ ${ }^{3}$ North-Ossetian State Medical Academy, Vladikavkaz, Russia \\ ${ }^{4}$ Douala General Hospital, Douala, Cameroon \\ ${ }^{5}$ Bio-Medical and Cancer Center of Bafoussam, Bafoussam, Cameroon \\ ${ }^{6}$ Maroua Regional Hospital, Maroua, Cameroon \\ ${ }^{7}$ Faculty of Medicine and Biomedical Sciences, The University of Yaoundé I, Yaoundé, Cameroon \\ ${ }^{8}$ Yaounde University Health Center, Yaoundé, Cameroon. \\ Email: jean_pen@yahoo.ca
}

Received 16 February 2016; accepted 16 March 2016; published 21 March 2016

Copyright ( 2016 by authors and Scientific Research Publishing Inc.

This work is licensed under the Creative Commons Attribution International License (CC BY).

http://creativecommons.org/licenses/by/4.0/

c) (i) Open Access

\section{Abstract}

Objective: To describe the epidemiological and histological aspects of cervical cancer in Cameroon. Materials and Methods: It was a descriptive retrospective study carried out over a period of 10 years (2005-2014), on malignant tumors of the cervix observed at the laboratory of Anatomic Pathology in four regions (Center, Littoral, West, South-west). The studied parameters were frequency, age, sex, localization, histological type and the immuno-histochemical aspects. Results: A total of 2078 cases with an annual frequency of 20.78 cases were registered; the peak was reached in 2010 with 304 cases (14.62\%). Cervical cancer was the main genital cancer affecting women with a percentage of $82.26 \%$. The average age of the patients was $52.33 \pm 12.80$ years old, with extremes from 22 to 93 years old. The age group from 40 to 59 had more than half of the cases, with 1094 cases $(52.65 \%)$. The major histological types recorded were squamous cell cancer with 1687 cases $(81.51 \%)$ and adenocarcinoma with 269 cases $(12.95 \%)$. Conclusion: Cervical cancer is the chief genital cancer affecting female genital organs. The predominant histological types are squamous cell cancers.

${ }^{*}$ Corresponding author.

How to cite this paper: Paul, E.N.J., Charlotte, T.N., Jules, O.M.L., Godefroy, S., Daniel, E.S.J., Michelle, E.F.A., Louis, E.O.J. and Alan, H. (2016) Epidemiological and Histological Profile of Cervical Cancer in Cameroon: About 2078 Cases. Open Journal of Obstetrics and Gynecology, 6, 232-239. http://dx.doi.org/10.4236/ojog.2016.64029 


\section{Keywords}

\section{Cancer, Cervix, Epidemiology, Histopathology, Cameroon}

\section{Introduction}

Cervical cancer is the second most commonly diagnosed cancer and the third leading cause of cancer death among females in less developed countries. Incidence rates are the highest in countries with low income [1]. Nearly $90 \%$ of cervical cancer deaths occurred in developing parts of the world [1]. In sub-Saharan Africa, the annual incidence is 34.8 new cases per 100,000 women with annual mortality of 22.5 deaths per 100,000 women [2]. The WHO recognizes three categories of epithelial tumors of the cervix: squamous, glandular (adenocarcinoma), and other epithelial tumors including neuroendocrine tumors and undifferentiated carcinoma [3]. Depending on stage, primary treatment consists of surgery, radiotherapy, or a combination of radiotherapy and chemotherapy [3]. In Europe, 5-year survival rate is estimated to 62\% for women diagnosed with cervical cancer [4]. In Africa, that rate is less than 60\% (Gambia-21.8\%, Uganda-45.8\%, Zimbabwe-57.8\%) [5]. In Cameroon, in 2012, cervical cancer was the second after breast cancer in Yaoundé [6]. The incidence of cancer continues to increase according to the recent studies. According to the results obtained by Sando et al. at the Gynaecological and Paediatric Hospital of Yaounde in 2013, it was 49.5\% [7]. In a multicenter study conducted in the Littoral region in 2015, it represented $72.32 \%$ of all genital cancers, while $94.48 \%$ of malignant tumors were epithelial [8]. All these works are limited to their study framework and may not reflect the general idea; these are reasons why we made this multicenter study to present the epidemiological and histopathological profile of this serious disease in Cameroon.

\section{Materials and Methods}

This is a descriptive and retrospective study over a period of 10 years (from January 2005 to December 2014), concerning cervical cancers in four regions (Center, Littoral, West and South-west) of Cameroon. The study protocol was approved by Ethics Committee of all the concerned institutions. The patients were from gynecology or oncology services in different health centers of the country. The samples examined were mainly composed of biopsies and surgical specimens obtained from women suspected of cervical cancer. These tissue specimens were fixed in $10 \%$ formalin and processed according to the usual techniques of paraffin embedding, microtome cutting and staining with hematoxylin-eosin. Only those women for whom the diagnosis was confirmed by the histology were included in the study. The data consisted of independent variables such as patient frequency, age, histological type of the tumor. The dependent variable concerned the cervical cancer confirmed by histology. The analysis of variables was performed with the Statistical Package for Social Sciences (SPSS), as 16.0. The elements of descriptive statistics were used to calculate the frequencies and proportions.

\section{Results}

\subsection{Epidemiological Aspects}

\subsubsection{Frequency of Genital Cancers in Women}

From 2005 to 2014, 2559 cases of genitals cancers in women were observed. Cervical cancer was the most frequent malignant tumour (2078 cases; $81.20 \%$ ), followed by ovarian cancer (199 cases; $7.78 \%$ ), as shown in Figure 1 below.

\subsubsection{Age}

The average age of patients was $52.33 \pm 12.80$ with extremes ranging from 22 to 93 years old. The peak incidence was noted with patients from 40 to 49 years old with a percentage of $27.28 \%$ (578 cases) as shown in Figure 2.

\subsection{Histopathological Aspects}

\subsubsection{Indication of the Histological Examination}

Concerning clinical presentation of cervical cancers, their frequency is reported by Table 1 . Ulcerative budding 


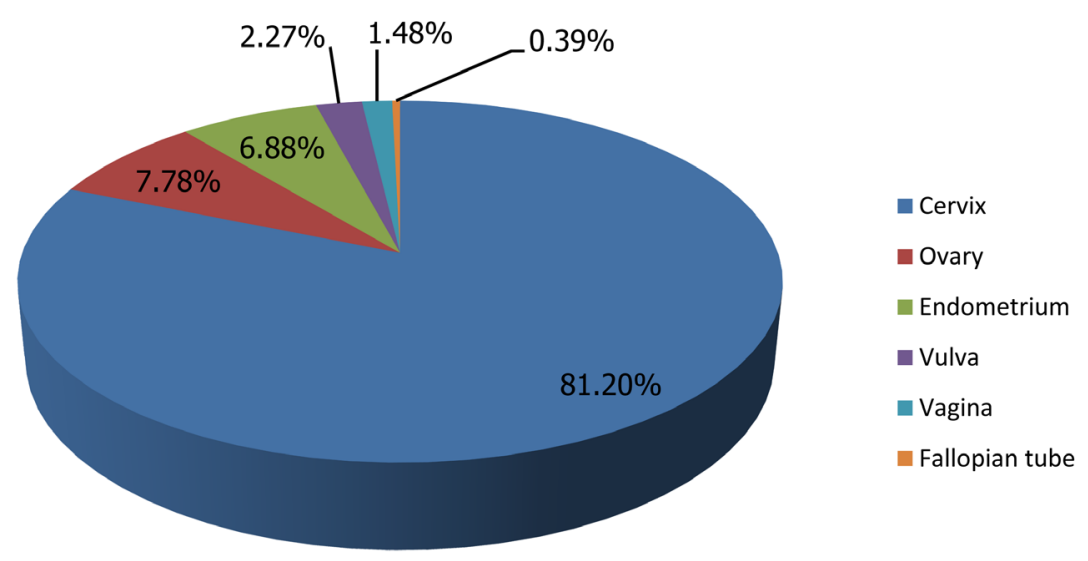

Figure 1. Distribution of genital cancers in women by seat.

Effective

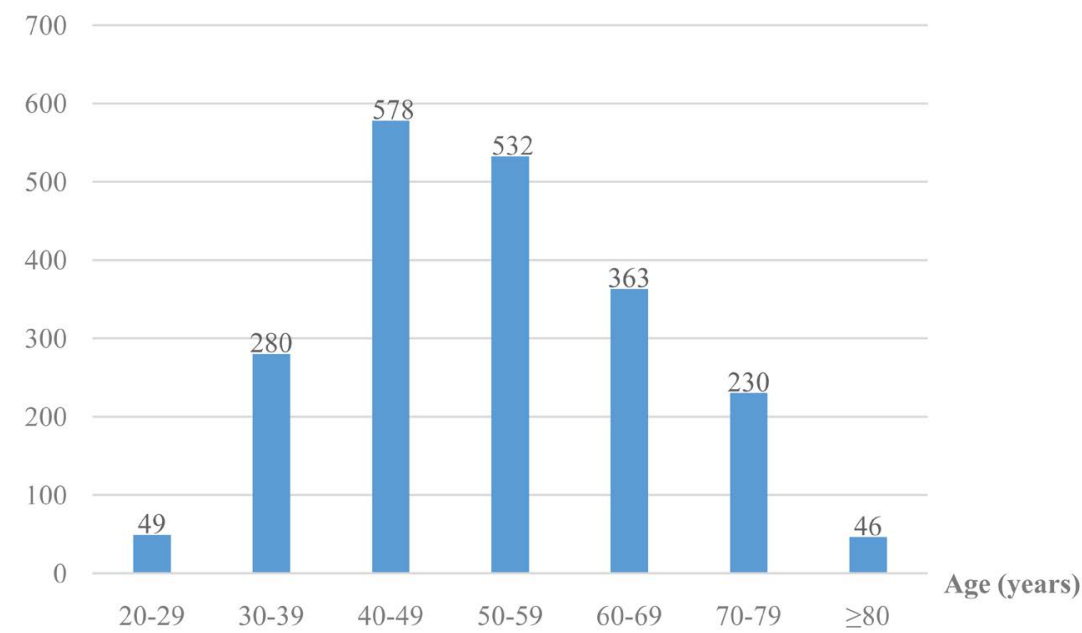

Figure 2. Distribution according to age groups.

Table 1. Distribution of clinical presentation.

\begin{tabular}{ccc}
\hline Clinical presentation & Effective (n) & Percentage (\%) \\
\hline Polypoid lesions & 71 & 13.65 \\
Ulcerative budding & 324 & 62.31 \\
Bleeding & 105 & 20.19 \\
Induration & 20 & 3.85 \\
\hline
\end{tabular}

was predominant (62.31\%), followed by bleeding (20.19\%).

\subsubsection{Histological Types}

Table 2 shows the distribution of histological types of cancers diagnosed during the study. A total of 1687 (81.18\%) cases of squamous cell carcinoma (SCC) and 269 (12.95\%) cases of adenocarcinoma (ADK) have been identified (Figures 3-5).

\section{Discussion}

The cervical cancer is the most frequent genital cancer in women in our series (81.20\%). This proportion is 
Table 2. Relationship between histological types and age.

\begin{tabular}{|c|c|c|c|c|c|c|c|}
\hline \multirow{2}{*}{ Ages } & \multicolumn{7}{|c|}{ Histological types of cervical cancer } \\
\hline & SCC & $\mathrm{ADK}$ & UC & ASC & NHL & Sarcoma & Total \\
\hline $20-21$ & 35 & 8 & 2 & 4 & 0 & 0 & 49 \\
\hline $30-39$ & 230 & 35 & 9 & 7 & 0 & 0 & 280 \\
\hline $40-49$ & 455 & 90 & 13 & 14 & 2 & 4 & 578 \\
\hline $50-59$ & 425 & 77 & 7 & 17 & 2 & 4 & 532 \\
\hline $60-69$ & 308 & 33 & 8 & 14 & 1 & 0 & 363 \\
\hline $70-79$ & 200 & 18 & 5 & 4 & 0 & 1 & 230 \\
\hline$\geq 80$ & 35 & 8 & 1 & 1 & 0 & 1 & 46 \\
\hline Total & 1687 (81.18\%) & 269 (12.95\%) & 45 (2.17\%) & 62 (2.98\%) & $5(0.24 \%)$ & $10(0.48 \%)$ & 2078 (100\%) \\
\hline
\end{tabular}

Note: SCC: Squamous cell carcinoma; ADK: Adenocarcinoma; UC: Undifferentiated Carcinoma, ASC: Adenosquamous Carcinoma; NHL: NonHodgkin's lymphoma.

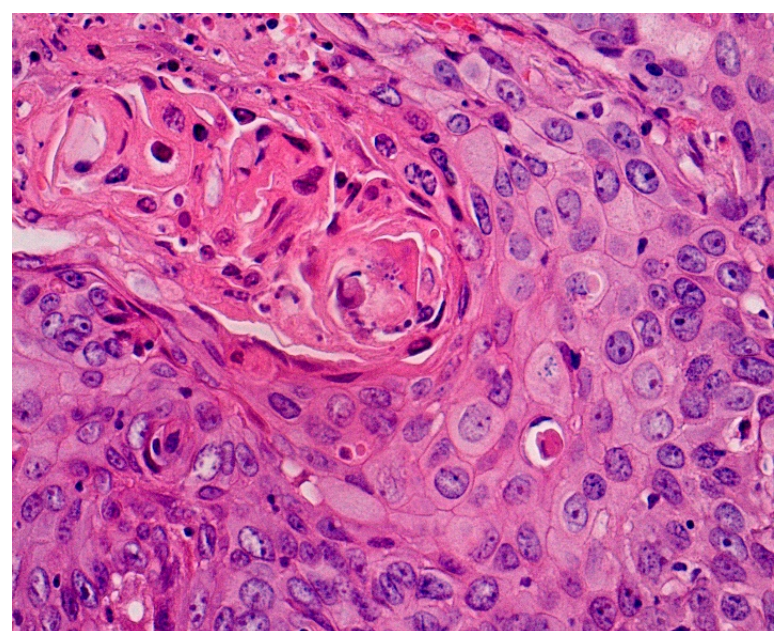

(a)

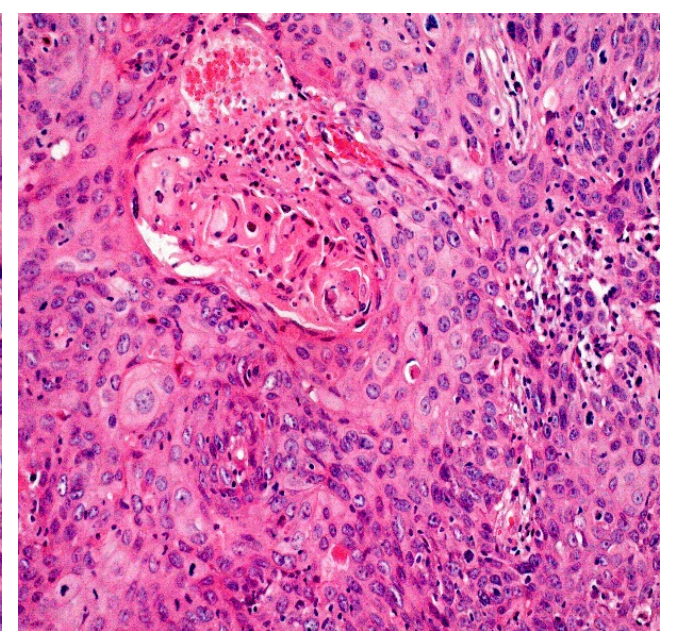

(b)

Figure 3. Well differentiated SCC (a) 400×; (b) 200×.

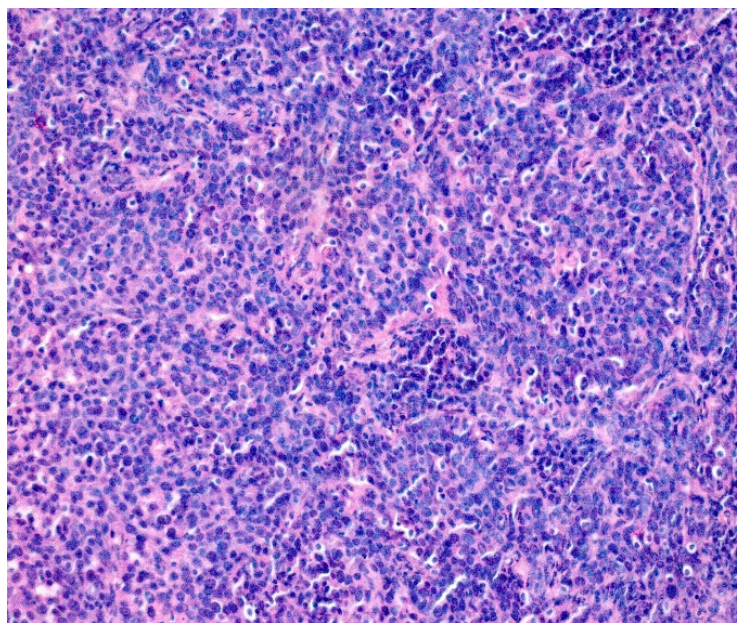

(a)

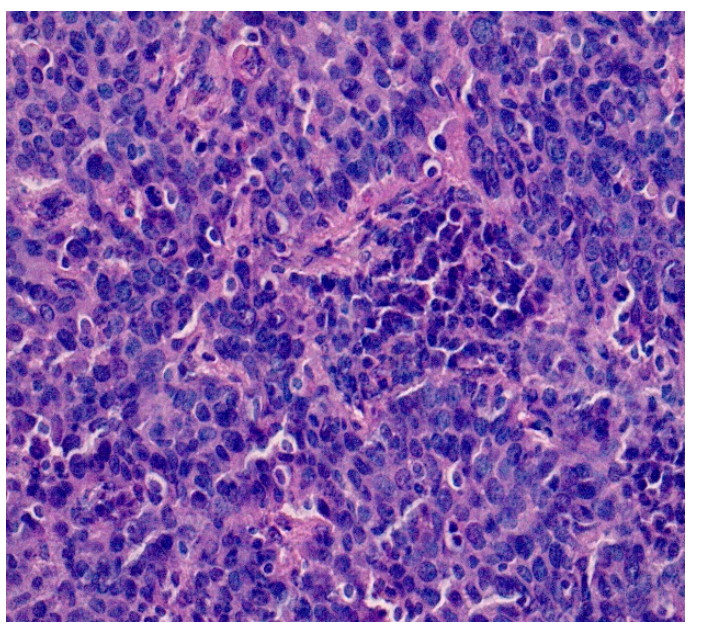

(b)

Figure 4. Poorly differentiated SCC (a) 200×; (b) 400×. 


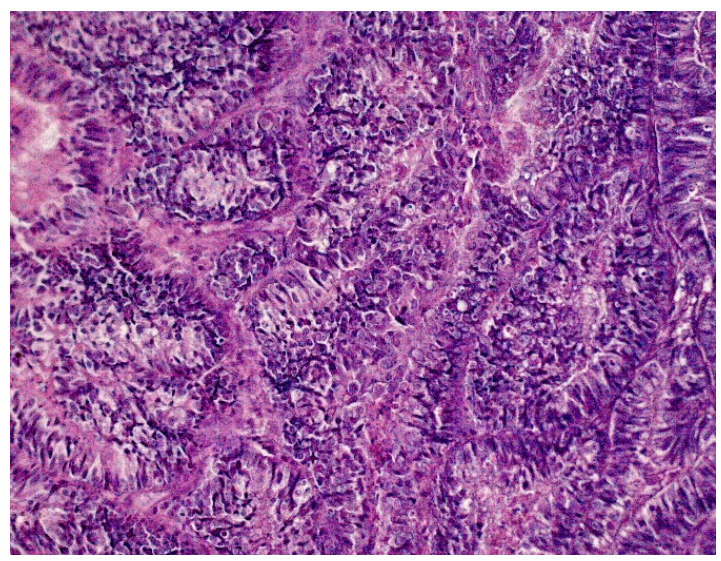

(a)

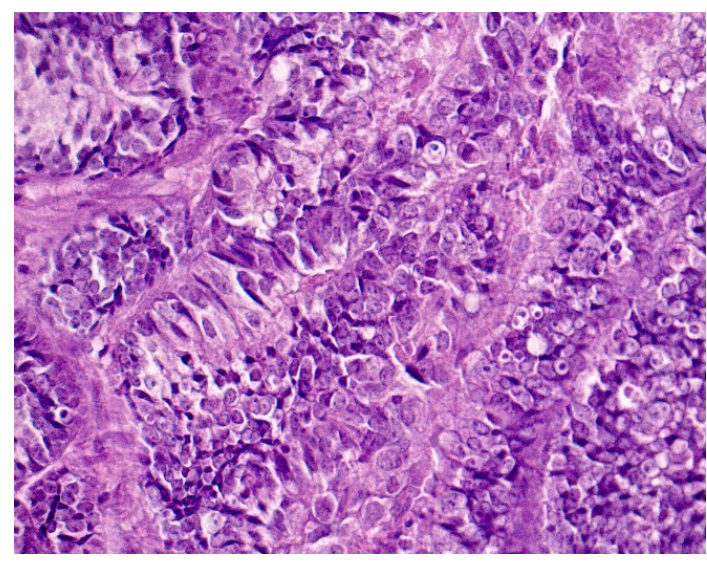

(b)

Figure 5. Well differentiated ADK (a) 200×, (b) 400×.

higher than what we found in the Littoral region of Cameroon in 2015, which was 72.32\% [8]. It, however, remains lower than that found by N'Dah et al. in Ivory Coast (82.85\%) [9]. The results of the study conducted on the incidence of cancer in Yaoundé in 2012, shows that cervical cancer was the second cancer after breast cancer [6], and represented $13.8 \%$ of all cancers irrespective of gender. The prevalence among young women in low-income countries is related to the existence of numerous risk factors and the lack of screening policy. According to some studies, Human papillomavirus (HPV) types 16, 18, 31, 33, 35, 39, 45, 51, 52, 56, 58, and 59 are classified as causes of cervical cancer [3] [5] [9]. Fewer than 10\% of persistent HPV infections progress to in situ carcinoma, if left untreated, can progress to cervical cancer [10] [11]. HPV16 and HPV18 account for 58\% and $16 \%$ respectively of all cervical cancer cases [12]. Other factors can be also act as cofactors in the progression of HPV infection toward cancer. Some of them are early unprotected sex, tobacco consumption, multi-sexual partner, cervix and vaginal recurrent infections, multiple pregnancies and immunodeficiency [5] [13]. Cervical squamous cell carcinoma risk is 1.5 times higher in current smokers than in people who have never smoked [14]. Cervical cancer risk is almost three times higher in women who had 6 or more sexual partners, compared to those who had only one [15].

The average age of patients was $52.33 \pm 12.80$ years old. This age is superimposed on those found in Yaoundé by Sando et al. (52.73 \pm 3.82 years), Engbang et al. in Douala (51.22 \pm 11.93 years old), and Elmajjawi et al. Morocco, in his series of 696 cases that had an average age of 50 years [7] [8] [16]. But this age is greater than the 47.36 years old mentioned by N'Dah et al. in Ivory Coast and the 49.5 years old indicated by Hasiniatsy et al. in Madagascar [9] [17]. The age group from 40 to 59 years old recorded the majority of cases (52.65\%), as in the N'Dah's series where patients from 45 to 54 years made up the majority of cases [9]. This is closed to the Western values where the average age of women with cervical cancer is around 51 years [18]. Aging is also a risk factor for persistent infection. The rate of persistent high-risk infection for women older than age 55 is $50 \%$, while the persistent rate of women younger than 25 years old is 20\% [19]. Cervical cancer is extremely rare in women younger than age 20. However, many young women become infected with multiple types of human papilloma virus, which then can increase their risk of getting cervical cancer in the future. Early age at first intercourse is consistently found to be a risk factor in most of the early epidemiological studies of cervical cancer [15] [20]. Cervical cancer risk is double in women who first had sexual intercourse at the age of 14 or less, compared to those who did at 25 or more [15]. The importance of early age at first coitus lies in the fact that intercourse introduces a carcinogenic agent (HPV infection) to the cervical epithelium, which is most susceptible during adolescence [20]. It can be viewed as a proxy for time of HPV infection or the start of the latent period, and the effect of early age at first intercourse could be a reflection of a longer duration of exposure [20]. Use of oestrogen-progestagen contraceptives is also a cause of cervical cancer [21]. Cervical cancer risk is double in current oral contraceptives (OC) users who have used OCs for 5 or more years, compared to people who have never used it [21]. Cervical cancer risk may increase with longer duration of use, but is no higher in women who last took OCs 10 or more years than in those who have never used it [22].

The clinical aspect was described only in 520 patients (25.50\%). The Ulcerative budding was the most com- 
mon sign in $62.31 \%$ of cases, followed by the bleeding $20.19 \%$, polypoid lesions $13.65 \%$ and induration $3.85 \%$. N'Dah et al., in their series have found ulcerative budding to be the main symptoms in $79.43 \%$ of cases, followed by polypoid lesions (9.21\%) and induration was the fourth with 5.19\% [9]. This is in contrast with Hasiniatsy et al. in which the main inaugural symptom was an advanced bleeding found in $71.87 \%$ of the cases [17]. Almost all cervical cancers contain traces of the human papilloma virus (HPV), which is also causative in the cellular changes that bring about ASC-US (abnormal squamous cells of uncertain significance), LGSILs (lowgrade squamous intraepithelial lesions) and HGSILs (high-grade squamous intraepithelial lesions) [23]. It is thought to infect basal cells within the cervical epithelium gaining access via minor trauma, or at the squamocolumnar junction [23] [24]. However, while HPV is sexually transmitted, the mechanism whereby a malignancy develops is not. The event that transforms a transient infection into cellular dysplasia or cancer is not fully understood. Integration of HPV into the cell genome is considered as an important step in the process [24]. The immune status is probably a significant factor [23].

Histologically, SCC was the predominant type with 1.687 (81.18\%) cases, followed by the ADK with 269 (12.95\%) cases. This predominance of the EC was discovered by several African authors. It is notably higher than the value found in the Cameroonian coast (72, 07\%) [8]. Other studies have assigned even higher values: Sando et al. -87.6\%, Hasiniatsy et al. -88.50\%, Nayama et al. -91.6\% and Elmajjawi et al. -94\% [7] [16] [17] [25]. However, in the West, Mubiayi et al. reported a trend applicable to ours with $81 \%$ cases of squamous cell carcinoma. However, more cases of adenocarcinoma were registered in their series, 17\% [26]. According to studies, cervical squamous cell carcinoma risk is 74\% - 80\% higher in women with a first-degree relative with cervical squamous cell carcinoma, compared to the general population [27]. Cervical adenocarcinoma risk is 39\% $69 \%$ higher in women with a first-degree relative with cervical squamous cell carcinoma, compared to the general population, a number of studies showed [27]. Cervical squamous cell risk is $15 \%$ higher in women who have had 1 full-term pregnancy than in those who have never had; the risk increases with the number of fullterm pregnancies [28]. The same study showed that cervical cancer risk among parous women is $77 \%$ higher in those under 17 at their first full-term pregnancy than in those aged 25 or more; the risk decreases with age at first full-term pregnancy [28]. There is no association with parity for adenocarcinoma [28]. Cervical squamous cell carcinoma risk is 1.5 times higher in current smokers than in people who have never smoked, and the risk increases with the number of cigarettes smoked per day [14].

\section{Conclusion}

Cervical cancer is a common disease in Cameroon where it is at the forefront of genital cancers in women. Squamous cell carcinoma is still the main histological type. Cervical cancer is preventable and curable in the very early stages of the disease. The implementation of a national screening policy, organization HPV vaccination and low cost screening programmes, can help to reduce the impact of cervical cancer in our population.

\section{References}

[1] Torre, L.A., Bray, F., Siegel, R.L., Ferlay, J., Lortet-Tieulent, J. and Jemal, A. (2015) Global Cancer Statistics, 2012. CA: A Cancer Journal for Clinicians, 65, 87-108. http://dx.doi.org/10.3322/caac.21262

[2] Ferlay, J., Soerjomataram, I., Ervik, M., Dikshit, R., Eser, S., et al. (2013) GLOBOCAN 2012 v1.0, Cancer Incidence and Mortality Worldwide. http://globocan.iarc.fr

[3] Colombo, N., Carinelli, S., Colombo, A., Marini, C., Rollo, D. and Sessa, C. (2012) Cervical Cancer: ESMO Clinical Practice Guidelines for Diagnosis, Treatment and Follow-Up. Annals of Oncology, 23, vii27-vii32. http://dx.doi.org/10.1093/annonc/mds268

[4] Sant, M., Lopez, M.D.C., Agresti, R., Pérez, M.J.S., et al. (2015) Survival of Women with Cancers of Breast and Genital Organs in Europe 1999-2007: Results of the EUROCARE-5 Study. European Journal of Cancer, 51, 2191-2205. http://dx.doi.org/10.1016/j.ejca.2015.07.022

[5] Sankaranarayanan, R., Swaminathan, R., Jayant, K., et al. (2011) An Overview of Cancer Survival in Africa, Asia, Caribbean and Central America: The Case for Investments in Cancer Health Services. IARC Scientific Publications, 162, 257-291.

[6] Enow, O.G.E., Ndom, P. and Doh, A.S. (2012) Current Cancer Incidence and trenDs in Yaounde, Cameroon. Oncology, Gastroenterology and Hepatology Reports, 1, 58-63. http://dx.doi.org/10.4103/2348-3113.133639

[7] Sando, Z., Fouogue, T.J., Fouelifack, Y.F., Fouedjio, H.J., Mboudou, T.E. and Essame, O.J.L. (2014) Profil des can- 
cers gynécologique et mammaire à Yaoundé-Cameroun. Pan African Medical Journal, 17, 28. http://dx.doi.org/10.11604/pamj.2014.17.28.3447

[8] Engbang, N.J.P., Mve, K.V., Tchente, N.C. and Fewou, A. (2015) Aspects histo-épidémiologiques des cancers génitaux de la femme dans la région du Littoral, Cameroun. Pan African Medical Journal, 21, 116. http://dx.doi.org/10.11604/pamj.2015.21.116.6755

[9] N’Dah, K.J., Doukoure, B., Troh, E., Aman, N.A., Koffi, K.E., Kouamé, A.D., et al. (2014) Epidemiological and Histological Aspects of Women Genital Cancers in Côte d’Ivoire. Open Journal of Obstetrics and Gynecology, 4, 516-523. http://dx.doi.org/10.4236/ojog.2014.49073

[10] Rositch, A.F., Koshiol, J. and Hudgens, M.G. (2013) Patterns of Persistent Genital Human Papillomavirus Infection among Women Worldwide: A Literature Review and Meta-Analysis. International Journal of Cancer, 133, 1271-1285. http://dx.doi.org/10.1002/ijc.27828

[11] Kulasingam, S.L., Havrilesky, L., Ghebre, R. and Myers, E.R. (2011) Screening for Cervical Cancer: A Decision Analysis for the U.S. Preventive Services Task Force. Rockville (MD): Agency for Healthcare Research and Quality (US). Evidence Syntheses, No. 86s. http://www.ncbi.nlm.nih.gov/books/NBK92546/

[12] Smith, J.S., Lindsay, L., Hoots, B., Keys, J., Franceschi, S., Winer, R. and Clifford, G.M. (2007) Human Papillomavirus Type Distribution in Invasive Cervical Cancer and High-Grade Cervical Lesions: A Meta-Analysis Update. International Journal of Cancer, 121, 621-632. http://dx.doi.org/10.1002/ijc.22527

[13] Cogliano, V.J., Baan, R., Straif, K., Grosse, Y., Lauby-Secretan, B., El Ghissassi, F., et al. (2011) Preventable Exposures Associated with Human Cancers. Journal of the National Cancer Institute, 103, 1827-1839. http://dx.doi.org/10.1093/jnci/djr483

[14] International Collaboration of Epidemiological Studies of Cervical Cancer (2006) Carcinoma of the Cervix and Tobacco Smoking: Collaborative Reanalysis of Individual Data on 13,541 Women with Carcinoma of the Cervix and 23,017 Women without Carcinoma of the Cervix from 23 Epidemiological Studies. International Journal of Cancer, 118, 1481-1495. http://dx.doi.org/10.1002/ijc.21493

[15] International Collaboration of Epidemiological Studies of Cervical Cancer (2009) Cervical Carcinoma and Sexual Behaviour: Collaborative Reanalysis of Individual Data on 15,461 Women with Cervical Carcinoma and 29,164 Women without Cervical Carcinoma from 21 Epidemiological Studies. Cancer Epidemiology, Biomarkers \& Prevention, 18, 1060-1069. http://dx.doi.org/10.1158/1055-9965.EPI-08-1186

[16] Elmajjaoui, S., Ismaili, N., Kharmoum, S., El kabbaj, H., Elkacemi, H., Elhassouni, K. et al. (2010) Cancer du col utérin : expérience du Maroc, à propos de 696 cas. Cancer/Radiothérapie, 14, 640-641. http://dx.doi.org/10.1016/j.canrad.2010.07.571

[17] Hasiniatsy, N.R.E., Ernestho-ghoud, I.M., Ralamboson, S.A., Rabarijaona, L.I. and Rafaramino, F. (2014) Prise en charge et suivi des cancers du col utérin: la réalité à Antananarivo, Madagascar. Journal Africain du Cancer, 6, 40-46. http://dx.doi.org/10.1007/s12558-014-0308-3

[18] Institut National du Cancer (2015) Les cancers en France en 2014. http://www.unicancer.fr/sites/default/files/

[19] Wright, J.D. (2014) Cervical intraepithelial neoplasia: Terminology, incidence, pathogenesis, and prevention. http://www.uptodate.com/contents/cervical-intraepithelial-neoplasia-terminology-incidence-pathogenesis-and-preventi on

[20] Biswas, L.N., Manna, B., Maiti, P.K. and Sengupta, S. (1977) Sexual Risk Factors for Cervical Cancer among Rural Indian Women: A Case-Control Study. International Journal of Epidemiology, 26, 491-495. http://dx.doi.org/10.1093/ije/26.3.491

[21] La Vecchia, C. and Boccia, S. (2014) Oral Contraceptives, Human Papillomavirus and Cervical Cancer (Link Is External). European Journal of Cancer Prevention, 23, 110-112.

[22] International Collaboration of Epidemiological Studies of Cervical Cancer, Appleby, P., Beral, V., et al. (2007) Cervical Cancer and Hormonal Contraceptives: Collaborative Reanalysis of Individual Data for 16,573 Women with Cervical Cancer and 35,509 Women without Cervical Cancer from 24 Epidemiological Studies. Lancet, 370, $1609-1621$. http://dx.doi.org/10.1016/S0140-6736(07)61684-5

[23] Dunleavey, R. (2004) Incidence, Pathophysiology and Treatment of Cervical Cancer. Nursing Times, 100, 38-41.

[24] Cooper, K., Evans, M. and Mount, S. (2003) Biology and Evolution of Cervical Cancer Squamous Intraepithelial Lesions: A Hypothesis with Diagnosis Implications. Advances in Anatomical Pathology, 10, 200-203. http://dx.doi.org/10.1097/00125480-200307000-00002

[25] Nayama, M., Nouhou, H., Madougou-Sunna, K., et al. (2006) Breast and Gynecological Cancers: Epidemiological and Histological Aspects Made from the Record of Pathology Laboratory of the Faculty of Science and Heath Niamey (Niger). Medical Journal of Mali, 31, 43-49.

[26] Mubiayi, N., Bogaert, E., Boman, F., Leblanc, E., et al. (2002) Histoire du suivi cytologique de 148 femmes atteintes 
d’un cancer invasif du col utérin. Gynécologie Obstétrique \& Fertilité, 30, 210-217. http://dx.doi.org/10.1016/S1297-9589(02)00297-7

[27] Hussain, S.K., Sundquist, J. and Hemminki, K. (2008) Familial Clustering of Cancer at Human Papillomavirus-Associated Sites According to the Swedish Family-Cancer Database. International Journal of Cancer, 122, 1873-1878.

http://dx.doi.org/10.1002/ijc.23265

[28] International Collaboration of Epidemiological Studies of Cervical Cancer (2006) Cervical Carcinoma and Reproductive Factors: Collaborative Reanalysis of Individual Data on 16,563 Women with Cervical Carcinoma and 33,542 Women without Cervical Carcinoma from 25 Epidemiological Studies. International Journal of Cancer, 119, 1108-1124. http://dx.doi.org/10.1002/ijc. 21953 